\title{
Electric power generation from treatment of food waste leachate using microbial fuel cell
}

\author{
Ze Jie Wang ${ }^{1,2}$, Bong Su Lim ${ }^{1+}$ \\ ${ }^{1}$ Department of Environmental Engineering, Daejeon University, Daejeon 34520, Republic of Korea \\ ${ }^{2}$ Qingdao Institute of Bioenergy and Bioprocess Technology, Chinese Academy of Sciences, Qingdao 266101, China
}

\begin{abstract}
Simultaneous treatment of food waste leachate and power generation was investigated in an air-cathode microbial fuel cell. A TCOD removal efficiency of $95.4 \pm 0.3 \%$ was achieved for an initial COD concentration of 2,860 $\mathrm{mg} / \mathrm{L}$. Maximum power density ranged was maximized at $1.86 \mathrm{~W} / \mathrm{m}^{3}$, when COD concentration varied between $60 \mathrm{mg} / \mathrm{L}$ and 2,860 mg/L. Meanwhile, columbic efficiency was determined between $1.76 \%$ and $11.07 \%$ for different COD concentrations. Cyclic voltammetric data revealed that the oxidation peak voltage occurred at $-0.20 \mathrm{~V}$, shifted to about $-0.25 \mathrm{~V}$. Moreover, a reduction peak voltage at $-0.45 \mathrm{~V}$ appeared when organic matters were exhausted, indicating that reducible matters were produced during the decomposition of organic matters. The results showed that it was feasible to use food waste leachate as a fuel for power generation in a microbial fuel cell, and the treatment efficiency of the wastewater was satisfied.
\end{abstract}

Keywords: COD removal, Electric power generation, Food waste leachate, Microbial fuel cell

\section{Introduction}

During the collection and treatment processes of food waste, large quantity of leachate would produce. In Korea, for example, it was reported as $9,077,000 \mathrm{~kg} / \mathrm{d}$ in 2007 , which was predicted to increase to $12,227,000 \mathrm{~kg} / \mathrm{d}$ by 2013 [1]. One of treatment strategies for food waste leachate is to discharge it into civil wastewater treatment plants [1]. The strategy can increase the operational cost, and waste valuable energies carried by organic matters and nutrient contents in the food waste leachate.

Tremendous attentions have been paid to microbial fuel cells (MFCs). MFCs could attract electric energy from organic matters, and thus they are promising technology to provide green energy and clean wastewater [2]. Exoelectrogens are with the ability to transfer electrons intracellularly to external electron acceptor, and thus they play core role of transferring electrons attracted from degradation of organic matter to the andic surface to close the process of electric power generation. Because of the extracellular electron transfer process, MFCs could accelerate the removal efficiency of organic matters and even they are able to degrade some persistence organic pollutants [3]. Several kinds of real organic wastewater were successfully treated with MFC technology.
Landfill leachate is high strength wastewater. In air-diffusion cathode MFC, $8.5 \mathrm{~kg} \mathrm{COD} \mathrm{m}^{-3} \mathrm{~d}^{-1}$ was removed and $344 \mathrm{mWm}^{-3}$ electric power was generated [4]. Similar treatment efficiency was determined to other kinds of high strength wastewaters, including swine wastewater [5], fermented wastewater [6], brewery wastewater [7, 8], and starch processing wastewater [9]. Food waste leachate contains rich organic matters, such as proteins and alcohol, and thus it should be an alternative substrate for power generation in MFCs. However, the feasibility of food waste leachate as substrate for power generation in MFCs has not yet been reported.

The purpose of the present study, therefore, is to evaluate the possibility of using food waste leachate as substrate for MFCs, and determine the removal efficiency of organic matters. Moreover, the performance of MFCs responding to initial COD concentration was as well compared.

\section{Materials and Methods}

\subsection{MFC Fabrication}

The volume of the air-diffusion cathode MFC was $234 \mathrm{~mL}(6.5 \mathrm{~cm}$ $\times 6 \mathrm{~cm} \times 6 \mathrm{~cm}$ ), with an effective volume of $200 \mathrm{~mL}$ (Fig. 1).
This is an Open Access article distributed under the terms of the Creative Commons Attribution Non-Commercial License (http://creativecommons.org/licenses/by-nc/3.0/) which permits unrestricted non-commercial use, distribution, and reproduction in any medium, provided the original work is properly cited.
Received May 1, 2016 Accepted November 21, 2016

${ }^{\dagger}$ Corresponding author

Email: bslim@dju.kr

Tel: +82-42-280-2531 Fax: +82-42-284-0109

Copyright (C) 2017 Korean Society of Environmental Engineers 


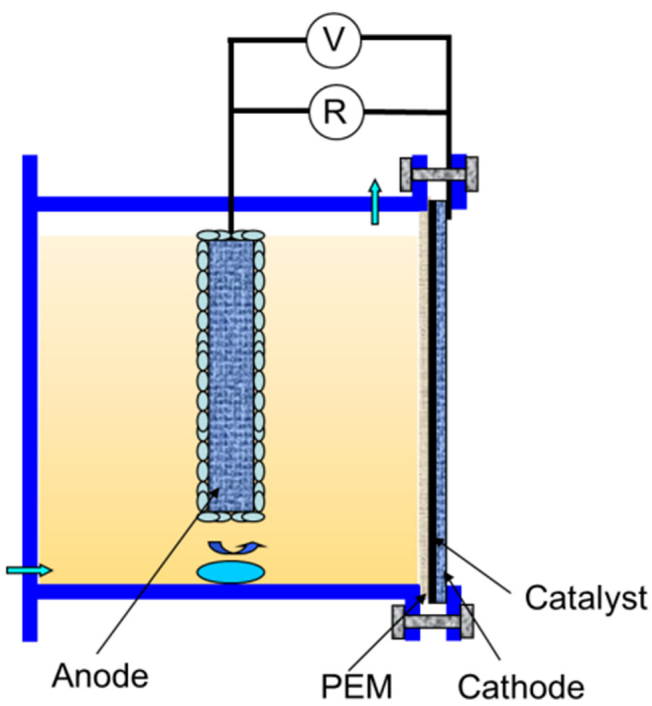

Fig. 1. Schematic of the air-cathode MFC reactor.

The anode was made of carbon felt with a geometrical surface area of $49.6 \mathrm{~cm}^{2}$, and the cathode was a commercially available ELAT $^{\circledR}$ gas diffusion electrode (Lot \#LT 120E-W: 090205) with Pt catalyst (20\%). Nafion 115 membrane (Alfar, USA) was pretreated as previously described [10]; then heat pressed to the catalyst side of the cathode at $120^{\circ} \mathrm{C}$. The membrane side was set to face the anodic solution. Titanium wire was used to connect anode and cathode.

\subsection{MFC Inoculation and Operation}

The inoculum was collected from the Okchen wastewater treatment plant (Okchen, Korea). To start up the MFC, $20 \mathrm{~mL}$ inoculum was mixed with $180 \mathrm{~mL}$ of artificial wastewater containing 1.05 g/L NH$H_{4} \mathrm{Cl}, 1.5 \mathrm{~g} / \mathrm{L} \mathrm{KH}_{2} \mathrm{PO}_{4}, 2.2 \mathrm{~g} / \mathrm{L} \mathrm{K} \mathrm{HPO}_{4}, 0.2$ g/L yeast extract, and $1.36 \mathrm{~g} / \mathrm{L} \mathrm{CH}_{3} \mathrm{COONa} \cdot 3 \mathrm{H}_{2} \mathrm{O}$ as electron donors [11]. When the voltage decreased below $30 \mathrm{mV}, 0.3 \mathrm{~g} \mathrm{CH}_{3} \mathrm{COONa} \cdot 3 \mathrm{H}_{2} \mathrm{O}$ was added to the anodic solution until consecutive stable voltages were achieved at least twice. After the MFC was successfully inoculated, the solution was replaced with food waste leachate. The food waste leachate was kept at $4^{\circ} \mathrm{C}$ in a refrigerator, and its characteristics were listed in Table 1.

Table 1. Characteristics of Food Waste Leachate

\begin{tabular}{cc}
\hline Parameters & Value \\
\hline $\mathrm{COD}, \mathrm{mg} / \mathrm{L}$ & $29,120 \pm 120$ \\
$\mathrm{pH}$ & $4.94 \pm 0.01$ \\
$\mathrm{SS}, \mathrm{mg} / \mathrm{L}$ & $1,920 \pm 80$ \\
$\mathrm{TN}, \mathrm{mg} / \mathrm{L}$ & $742.2 \pm 28.2$ \\
$\mathrm{TP}, \mathrm{mg} / \mathrm{L}$ & $121.8 \pm 6.9$ \\
$\mathrm{NH}_{3}-\mathrm{N}, \mathrm{mg} / \mathrm{L}$ & $160.04 \pm 2.36$ \\
${ }^{\mathrm{a}}$ Conductivity, mS/cm & $11.37 \pm 0.08$ \\
Salinity, ppt & $5.5 \pm 0.0$ \\
\hline
\end{tabular}

${ }^{a}$ at $32.7 \pm 0.3^{\circ} \mathrm{C}$
The food waste leachate was diluted to different initial COD concentrations with distilled water, and then buffered with 1.5 g/L $\mathrm{KH}_{2} \mathrm{PO}_{4}$ and $2.2 \mathrm{~g} / \mathrm{L} \mathrm{K}_{2} \mathrm{HPO}_{4}$. Cyclic voltammogram (CV) analysis was carried out with three-electrode configuration with anode as working electrode, cathode as counter electrode and $\mathrm{Ag} / \mathrm{AgCl}$ (3.3 $\mathrm{M} \mathrm{KCl}$ ) as reference electrode. The MFC was performed via batch mode and the anodic solution was stirred with a magnetic stirring bar. During the research, the temperature was controlled at $30 \pm 1^{\circ} \mathrm{C}$ in an incubator.

\subsection{Calculations}

Both voltage and CV were recorded with a pertentiostat (WMPG 1000, Won-A Tech, Korea). Power density $\left(\mathrm{W} / \mathrm{m}^{3}\right)$ were calculated according to $\mathrm{P}=\mathrm{V}^{2} / \mathrm{R} \bullet \mathrm{v}$, where $\mathrm{V}$ is the voltage across the external resistance (R), and $\mathrm{v}$ is the effective volume of anode chamber. Current and current density were calculated as $\mathrm{I}=\mathrm{V} / \mathrm{R}$ and $\mathrm{J}$ $=\mathrm{I} / \mathrm{v}$, respectively. Coulombic efficiency (CE) was calculated as $\mathrm{CE}=\mathrm{C}_{\mathrm{P}} / \mathrm{C}_{\mathrm{T}}$, where $\mathrm{C}_{\mathrm{P}}$ is the practical coulombs calculated by integrating the current over time, and $\mathrm{C}_{\mathrm{T}}$ is the theoretical coulombs available from removed COD. The internal resistance $\left(R_{\text {int }}\right)$ was determined as the slope of $\mathrm{I}-\mathrm{V}$ curve according to $\mathrm{V}=\mathrm{E}-\mathrm{I} \cdot \mathrm{R}_{\mathrm{int}}$, where $\mathrm{E}$ is electromotive force of the cell [12].

\section{Results and Discussion}

\subsection{Voltage Output}

With sodium acetate as an electron donor, a stable voltage of about $390 \mathrm{mV}$ across the external resistor was repeatedly obtained (Fig. 2(a), latest 3 cycles). Replacing artificial wastewater with food waste leachate, the voltage rose quickly to stable voltage of $270 \mathrm{mV}$ (Fig. 2(b)). The results demonstrated that organic components of food waste leachate were easily decomposed by exoelectrogens located on the surface of anode. After complete cycles, the TCOD decreased from 2,860 mg/L to $131.9 \pm 8.6 \mathrm{mg} / \mathrm{L}$, representing a removal efficiency of $95.4 \pm 0.3 \%$. The SCOD decreased by $96.2 \pm 0.6 \%$ from $2,664 \mathrm{mg} / \mathrm{L}$ to $101.2 \pm 15.6 \mathrm{mg} / \mathrm{L}$. The CE was used to indicate the recovery efficiency of electrons as electric current from the decomposition of organic matters. It was determined that the CE was $5.79 \pm 0.03 \%$ in the present study. It was similar to $6.7 \%$ to $8 \%$ with starch processing wastewater as fuel for MFC [9], however, it was larger than that $(<1 \%)$ when fermented wastewater was used for power generation [6]. Low $\mathrm{CE}$ indicated that large amount of electrons containing in organic matters was consumed by processes other than power output. Within the electroactive biofilm, many other species of microorganism than exoelectrogens exit, such as methanogenium [6]. The methanogenium could compete with exoelectrogens to take advantage of the organic matters to produce methane instead of electric current, and thus decreasing the CE of MFCs. Moreover, the environment of air-diffusion cathode MFC is not definitely anaerobic, and thus organic matters could be aerobically degraded by microorganism, which could as well reduce the CE [13].

For COD of $2,860 \mathrm{mg} / \mathrm{L}$, a maximum power density was determined as $1.53 \pm 0.11 \mathrm{~W} / \mathrm{m}^{3}$ at a current density of $8.75 \pm$ $0.31 \mathrm{~A} / \mathrm{m}^{3}$ (Fig. 3(a)). It was similar to $1.10 \mathrm{~W} / \mathrm{m}^{3}$ for real field 

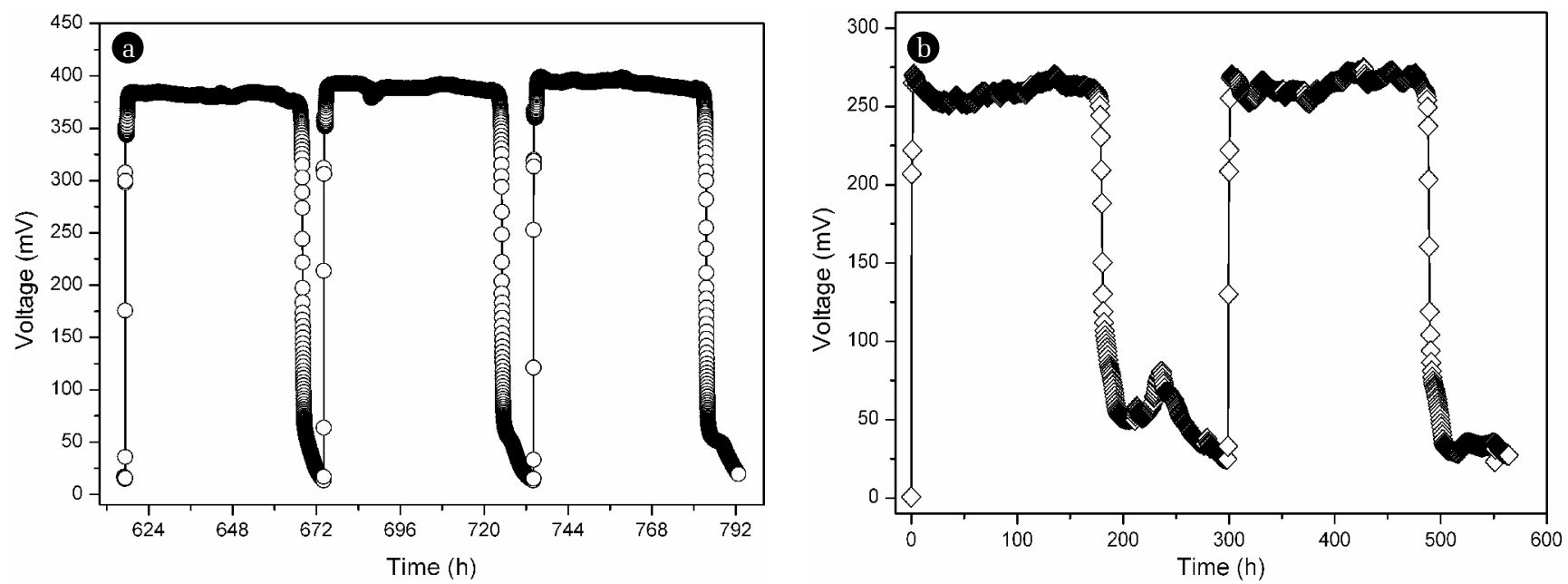

Fig. 2. Voltage output during the start-up period (a) and food waste leachate as fuel (b) (external resistor of $500 \Omega$ ).
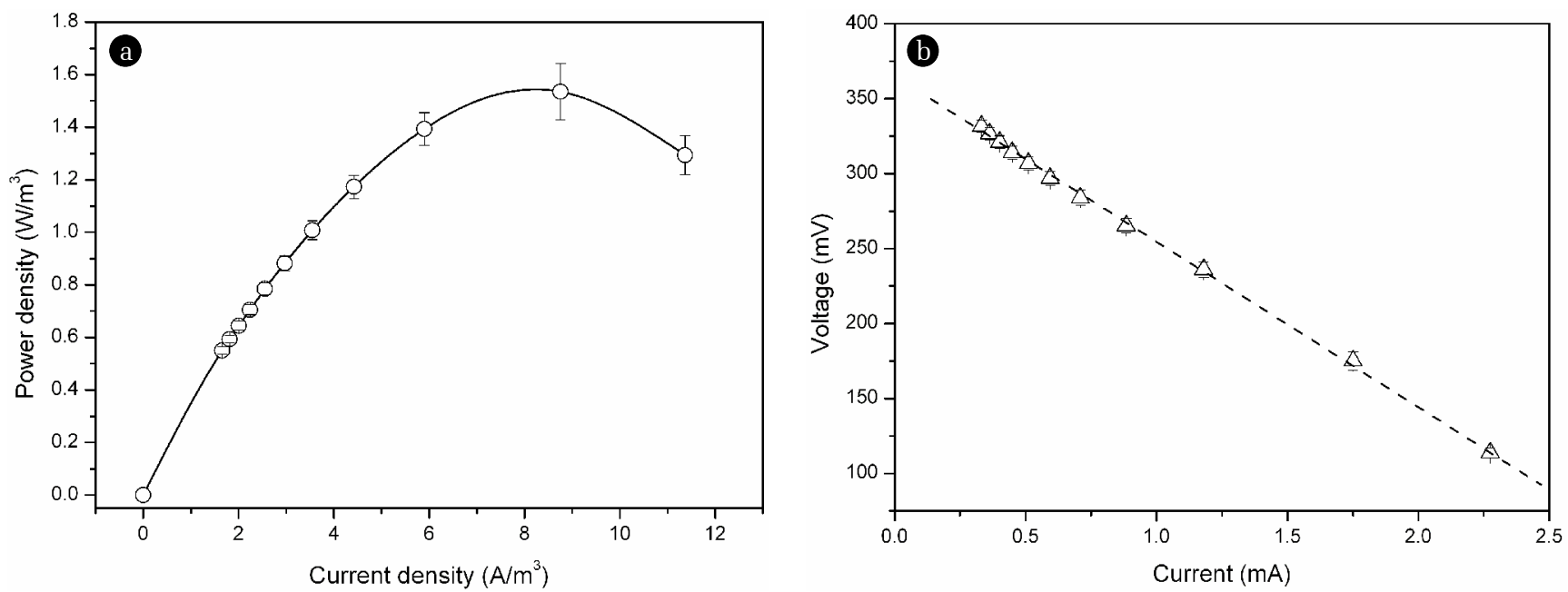

Fig. 3. Power densities at different current densities (a) and I-V curve (b) (external resistance from 1,000 $\Omega$ to $50 \Omega$, duplicate data).

dairy wastewater [14], $2.19 \mathrm{~W} / \mathrm{m}^{3}$ for animal carcass wastewater [15], and $2.21 \mathrm{~W} / \mathrm{m}^{3}$ for sea food processing wastewater as fuel [16], but it was smaller than $8.0 \mathrm{~W} / \mathrm{m}^{3}$ for real dye wastewater [17]. Moreover, the $R_{\text {int }}$ was determined as $109.95 \pm 3.95 \Omega$ (Fig. 3(b)). Performance of MFCs relies on couples of factors, such as the configuration, electrode material, operation parameter, and characteristics of the real wastewater [18]. The nature of wastewater would affect the community composition of the electroactive biofilm, and further influence the wastewater treatment efficiency and electric power generation [19].

\subsection{Effects of COD Concentration}

COD concentration could affect the performance of MFCs. Different COD concentrations $(60,110,275,580,878,2,160$, and 2,860 $\mathrm{mg} / \mathrm{L}$ ) were used to evaluate its influence on the electric power generation, $\mathrm{R}_{\text {int }}$, and $\mathrm{CE}$. The solutions were buffered with 1.5 $\mathrm{g} / \mathrm{L} \mathrm{KH}_{2} \mathrm{PO}_{4}$, and $2.2 \mathrm{~g} / \mathrm{L} \mathrm{K}_{2} \mathrm{HPO}_{4}$.

The maximum power density ranged between $1.19 \pm 0.04$ and
$1.86 \pm 0.003 \mathrm{~W} / \mathrm{m}^{3}$ for different initial COD concentrations (Fig. 4(a)). It was best fitted to the BoxLucas 1 model using OriginPro 7.5 program $\left(\mathrm{R}^{2}=0.973\right)$ according to the equation: $\mathrm{P}=\mathrm{P}_{\max }\left(1-\mathrm{e}^{-\mathrm{kCs}}\right)$, where $\mathrm{k}$ is the growth rate constant, and Cs is the substrate concentration. It meant that the maximum power density could be easily obtained even at a relatively low concentration of organic matter. At a COD concentration of $580 \mathrm{mg} / \mathrm{L}$, the largest maximum power density $\left(1.86 \pm 0.003 \mathrm{~W} / \mathrm{m}^{3}\right)$ was obtained due to the smallest $\mathrm{R}_{\text {int }}$ of $83.7 \pm 0.3 \Omega$ (Fig. 4(b)). $\mathrm{R}_{\text {int }}$ was calculated to be between $83.7 \pm 0.3$ and $116.95 \pm 1.55 \Omega$ for different initial COD concentrations.

Based on the same buffer concentration, a high COD concentration (low dilution ratio) led to a high solution conductivity, and an increase in solution conductivity would lower the $\mathrm{R}_{\text {int }}$ of MFC [12]. However, such a relation between conductivity and $\mathrm{R}_{\text {int }}$ was only observed when the COD concentration was not larger than $580 \mathrm{mg} / \mathrm{L}$. Larger COD concentration than $580 \mathrm{mg} / \mathrm{L}$ led to larger $\mathrm{R}_{\mathrm{int}}$. The reason for this might be that the concentration 

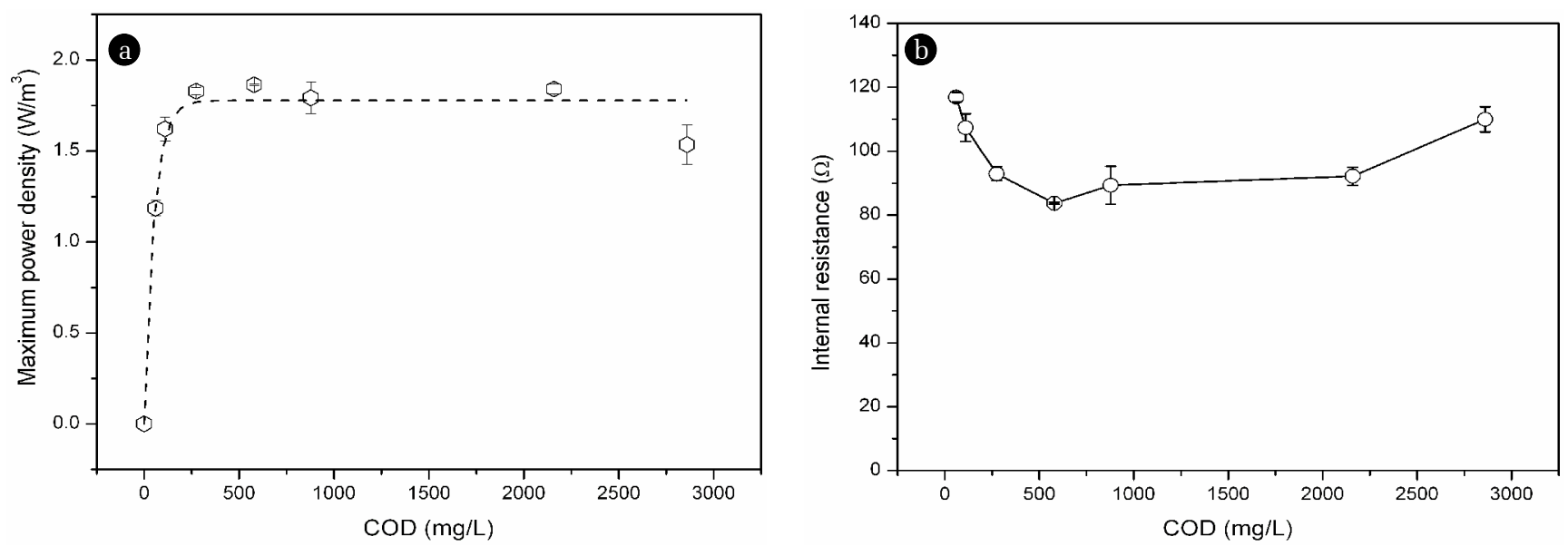

Fig. 4. Maximum power density (a) and internal resistance (b) for different COD concentrations (duplicate data).

Table 2. Comparison of CE for Different COD Concentration

\begin{tabular}{|c|c|c|c|c|c|}
\hline \multicolumn{3}{|c|}{ COD (mg/L) } & \multicolumn{2}{|c|}{ Coulomb (C) } & \multirow{2}{*}{$\begin{array}{c}\text { Coulombic } \\
\text { Efficiency (\%) }\end{array}$} \\
\hline Influent & Effluent & Removed & Generated & Recovered & \\
\hline 2,160 & $1,562.1 \pm 3.7$ & $597.9 \pm 3.7$ & $1,442.21 \pm 8$ & $25.4 \pm 0.7$ & $1.76 \pm 0.06$ \\
\hline 878 & $366.7 \pm 17.9$ & $511.0 \pm 17.9$ & $1,232.48 \pm 43$ & $26.5 \pm 0.1$ & $2.15 \pm 0.08$ \\
\hline 580 & $186.8 \pm 0.8$ & $393.3 \pm 0.8$ & $948.57 \pm 1.8$ & $26.3 \pm 0.1$ & $2.77 \pm 0.01$ \\
\hline 275 & $53.1 \pm 5.8$ & $221.9 \pm 5.8$ & $535.18 \pm 14$ & $26.35 \pm 0.15$ & $4.93 \pm 0.16$ \\
\hline 110 & $34.3 \pm 2.1$ & $75.8 \pm 2.1$ & $182.72 \pm 4.9$ & $20.3 \pm 3.3$ & $11.07 \pm 1.51$ \\
\hline 60 & 30.2 & 29.8 & 71.91 & 6.93 & 9.64 \\
\hline
\end{tabular}

of possibly existing harmful matters was high enough to limit the activity of exoelectrogens with low dilution ratio.

CE could be as well affected by the COD concentration. In the present study, the CE increased from $9.64 \%$ for a COD of $60 \mathrm{mg} / \mathrm{L}$ to $11.07 \pm 1.51 \%$ for a COD of $110 \mathrm{mg} / \mathrm{L}$, and then decreased to $1.76 \pm 0.06 \%$ for a COD of $2,160 \mathrm{mg} / \mathrm{L}$ (Table 2 , based on $12 \mathrm{~h}$ discharge). The inverse relationship between CE and COD concentration was also observed by other research [5]. It was because that higher COD concentration took longer time to be completely decomposed by microorganism, and therefore more oxygen could diffuse to the anodic chamber; more oxygen could provide more electron acceptors for aerobic microorganism to consume the organic matters, which further decreased the CE [5]. Based on the same reaction time in this study, harvested coulomb was not significantly different when the COD was saturated. However, removed COD was positively correlated to initial COD, which led to a low CE for high initial COD. It was implied that other factors besides to oxygen diffusion that could lower CE should be taken into consideration to improve $\mathrm{CE}$ when real wastewater was used to generate electric power in MFCs.

\subsection{Cyclic Voltammetry}

The Cyclic Voltammetry (CV) for initial and treated food waste leachate were performed with an initial COD of $580 \mathrm{mg} / \mathrm{L}$ (Fig. 5). Obviously, an oxidation peak was observed for the original food waste leachate at about $-0.20 \mathrm{~V}$. After the MFC cycle was complete, the oxidation peak decreased in intensity and shifted to about $-0.25 \mathrm{~V}$.

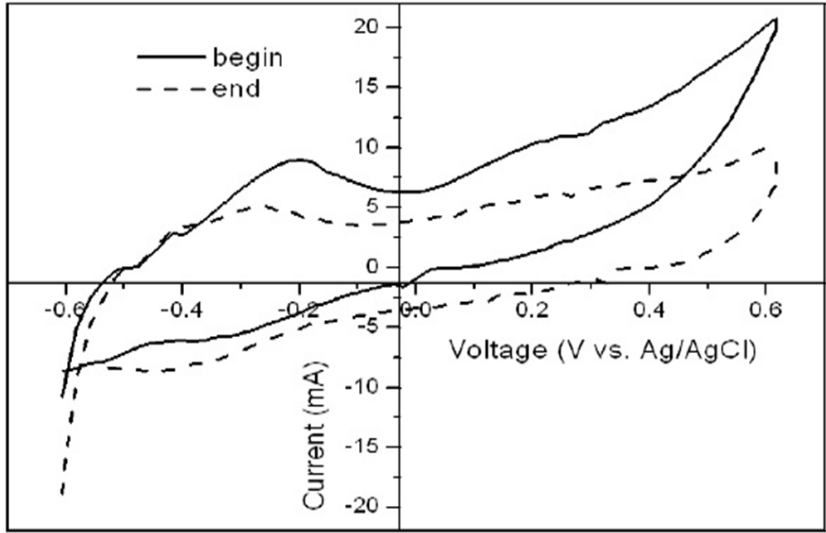

Fig. 5. CVs for initial and reacted solutions with an initial COD of $580 \mathrm{mg} / \mathrm{L}$ (scan rate of $50 \mathrm{mV} / \mathrm{s}$ ).

The decrease in the oxidation peak was possibly due to the decomposition of organic matters by the microbes, which further led to a substrate limitation to the exoelectrogens. When the organic matter was decomposed, however, the reduction current was increased and a current peak appeared at about $-0.45 \mathrm{~V}$. The increased reduction current in the CV curve was likely incurred by the produced reducible matters during the decomposition process of organic matters. Moreover, the peak current voltage of $-0.45 \mathrm{~V}$ was larger than previously reported voltage of $-0.34 \mathrm{~V}$ for $\mathrm{NAD}+\mathrm{NADH}[20]$. It is implied that the electroactivity of the 
biofilm in the present was more robust, probably due to that some exoelectrogens within the biofilm obtained high ability to transfer electrons from the microbe to the anodic surface.

\section{Conclusions}

In the present research, electric power generation coupled with food waste leachate treatment using air-diffusion cathode MFC was successfully studied. The removal efficiency of COD was determined to be as high as $95.4 \pm 0.3 \%$, when the COD concentration was $2,860 \mathrm{mg} / \mathrm{L}$. The maximum power density ranged was maximized at $1.86 \mathrm{~W} / \mathrm{m}^{3}$, with COD concentration ranged of $60-2,860$ $\mathrm{mg} / \mathrm{L}$. CV experiments showed that reducible matters were produced during the process of food waste leachate decomposition and implied that exoelectrogens with high ability to transfer electrons existed within the biofilm on the anode.

\section{References}

1. Korean Ministry of Environment. Study on development on optimum models and facilitating/operational guide line according to methods for energy generation of food waste and leachate. Sejong: Ministry of Environment; 2008.

2. Wang Z, Lee T, Lim B, Choi C, Park J. Microbial community structures differentiated in a single-chamber air-cathode microbial fuel cell fueled with rice straw hydrolysate. Biotech. Biofuels 2014;7:9.

3. Wang L, Liu Y, Ma J, Zhao F. Rapid degradation of sulphamethoxazole and the further transformation of 3-amino-5-methylisoxazole in a microbial fuel cell. Water Res. 2016;88:322-328.

4. Puig S, Serra M, Coma M, Cabré M, Balaguer MD, Colprim J. Microbial fuel cell application in landfill leachate treatment. J. Hazard. Mater. 2011;185:763-767.

5. Min B, Kim JR, Oh SE, Regan JM, Logan BE. Electricity generation from swine wastewater using microbial fuel cells. Water Res. 2005;39:4961-4968.

6. Nam JY, Kim HW, Lim KH, Shin HS. Effects of organic loading rates on the continuous electricity generation from fermented wastewater using a single-chamber microbial fuel cell. Bioresour. Technol. 2010;101:33-37.

7. Wen Q, Wu Y, Cao DX, Zhao LX, Sun Q. Electricity generation and modeling of microbial fuel cell from continuous beer brewery wastewater. Bioresour. Technol. 2009;100:4171-4175.
8. Wang X, Feng YJ, Lee H. Electricity production from beer brewery wastewater using single chamber microbial fuel cell. Water Sci. Technol. 2008;57:1117-1121.

9. Lu N, Zhou S-G, Zhuang L, Zhang J-T, Ni J-R. Electricity generation from starch processing wastewater using microbial fuel cell technology. Biochem. Eng. J. 2009;43:246-251.

10. Chae KJ, Choi MJ, Ajayi FF, Park WS, Chang IS, Kim IS. Mass transport through a proton exchange membrane (Nafion) in microbial fuel cells. Energ. Fuel. 2008;22:169-176.

11. Ramasamy RP, Ren ZY, Mench MM, Regan JM. Impact of initial biofilm growth on the anode impedance of microbial fuel cells. Biotechnol. Bioeng. 2008;101:101-108.

12. Liu H, Cheng SA, Logan BE. Power generation in fed-batch microbial fuel cells as a function of ionic strength, temperature, and reactor configuration. Environ. Sci. Technol. 2005;39:5488-5493.

13. Cheng SA, Liu H, Logan BE. Increased performance of single-chamber microbial fuel cells using an improved cathode structure. Electrochem. Comm. 2006;8:489-494.

14. Mohan SV, Mohanakrishna G, Velvizhi G, Babu VL, Sarma PN. Bio-catalyzed electrochemical treatment of real field dairy wastewater. Biochem. Eng. J. 2010;51:32-39.

15. Li X, Zhu N, Wang Y, Li P, Wu P, Wu J. Animal carcass wastewater treatment and bioelectricity generation in up-flow tubular microbial fuel cells: Effects of HRT and non-precious metallic catalyst. Bioresour. Technol. 2013;128:454-460.

16. Jayashree C, Tamilarasan K, Rajkumar M, et al. Treatment of seafood processing wastewater using upflow microbial fuel cell for power generation and identification of bacterial community in anodic biofilm. J. Environ. Manage. 2016;180:351-358.

17. Kalathil S, Lee J, Cho MH. Efficient decolorization of real dye wastewater and bioelectricity generation using a novel single chamber biocathode-microbial fuel cell. Bioresour. Technol. 2012;119:22-27

18. Rinaldi A, Mecheri B, Garavaglia V, Licoccia S, Di Nardo P, Traversa E. Engineering materials and biology to boost performance of microbial fuel cells: A critical review. Energy Environ. Sci. 2008;1:417-429.

19. Chae KJ, Choi MJ, Lee JW, Kim KY, Kim IS. Effect of different substrates on the performance, bacterial diversity, and bacterial viability in microbial fuel cells. Bioresour. Technol. 2009;100:3518-3525

20. Wang Z, Lim B, Lu H, Fan J, Choi C. Cathodic reduction of $\mathrm{Cu}^{2+}$ and electric power generation using a microbial fuel cell. Bul. Korean Chem. Soc. 2010;31:2025-2030. 